\title{
The influence of meteorological factors on phytochemical composition of Artemisia pontica $\mathrm{L}$.
}

\author{
Sandra Saunoriūtè $\dot{e}^{1,2 *}$, \\ Ona Ragažinskiené ${ }^{2}$, \\ Liudas Ivanauskas ${ }^{3}$, \\ Mindaugas Marksa ${ }^{3}$, \\ Erika Šeinauskienè $\dot{e}^{2}$ \\ ${ }^{1}$ Department of Biology, \\ Faculty of Natural Science, \\ Vytautas Magnus University, \\ 8 Vileikos Street, \\ 44404 Kaunas, Lithuania
}

${ }^{2}$ Scientific Sector of Medicinal

and Aromatic Plants,

Scientific Department,

Botanical Garden,

Vytautas Magnus University,

$6 \check{Z}$. E. Žilibero Street,

46324 Kaunas, Lithuania

${ }^{3}$ Department of Analytical

and Toxicological Chemistry,

Faculty of Pharmacy,

Lithuanian University of Health Science,

13 Sukileliu Street,

50162 Kaunas, Lithuania
In order to increase the diversity of medicinal plants and biologically active compounds accumulated in them, considerable attention is given to introduction of Artemisia L. genus plants in Lithuania. The aim of our study was to determinate the qualitative and quantitative composition of essential oils of Artemisia pontica L. introduced in Lithuania. The object of investigation - Artemisiae pontici herba were prepared in the Scientific Sector of Medicinal and Aromatic Plants, Scientific Department of Botanical Garden at Vytautas Magnus University in 2018-2019. Essential oils were separated by hydrodistillation method, their composition was analysed by gas chromatography/mass spectrometry methods in the Faculty of Pharmacy at Lithuanian University of Health Sciences in 2018-2020. The obtained results showed that a statistically significant $(p>0.05)$ higher amount and diversity of compounds from Artemisiae pontici herba essential oils were assessed in 2018 when HTC $=1.32$. A strong correlation $(r=0.740)$ was assessed between the average of active temperatures and precipitation in 2019. The content of compounds was by $33.3 \%$ lower when $\mathrm{HTC}=0.91$. The other major compounds were 1,8 -cineole $(46.86 \%)$, 1,4-cineole (37.92\%) and camphor (29.41-33.02\%).

Keywords: Artemisiae pontici herba, meteorological factors, essential oils, 1,8-cineole, 1,4-cineole, camphor

\section{INTRODUCTION}

Over the past few years, the medicinal plants and biologically active compounds of Artemisia L. genus are given a wide recognition and considerable attention [7, 8, 12]. In 2015, Chinese scientist Tu Youyou was awarded the Nobel Prize for research of biologically active compounds of Artemisia annua L. and their effects on human body [9]. The World Health Organization recommends ar-

*Corresponding author. Email: sandra.saunoriute@vdu.lt temisinin for the treatment of malaria [ $4,14,24$. Other species of Artemisia L. genus have ecological plasticity and are promising in the treatment caused by diseases of various oxidative stress lesions $[1,11,13,16]$.

The object of investigation was Artemisia pontica L. (Roman wormwood), a herbaceous, medicinal, aromatic plant of the Asteraceae (Bercht. \& J. Presl) family. The plant is perennial, $30-60 \mathrm{~cm}$ in height, flowering by August-September, distributed in Central and South Europe, European part of Russia, western Siberia, the Caucuses and Middle 
Asia [5, 10]. However, it is now cultivated worldwide due to its various medicinal uses. A. pontica is widely used in folk medicine and alcohol industry for the production of vermouth [6, 10].

In the literature, there are only a few papers dealing with the essential oil composition and properties of this species from different geographic locations. Analysis of the chemical composition of $A$. pontica oils extracted from plants grown in France showed $\beta$-farnese, iso-artemisia ketone, $\alpha$-thujone and 1,8-cineole as the main components [6]. In the study of Vincenzi et al., the main compound found in the oils of A. pontica was eucalyptol [19]. However, there is no available data for a complex evaluation of the antimicrobial and antioxidant activities of essential oil from A. pontica.

The aim of our study was to determine the qualitative and quantitative composition of the essential oils obtained from Artemisiae pontici herba, depending on meteorological factors. Considering that there are scare reports in the literature of research carried out with $A$. pontica, this article aimed to establish for the first time the chemical composition of its essential oils in Lithuania.

\section{EXPERIMENTAL}

\section{Plant material}

Artemisia pontica L. was introduced in the Middle of Lithuania, ex situ in the Collection of Medicinal Plants of the Scientific Sector of Medicinal and Aromatic Plants, Scientific Department of Botanical Garden at Vytautas Magnus University (VMU) since 1973, Collection No. LT-KAUN-1973-O0070, coordinates on the map 54.871219, 23.916526. Artemisiae pontici herba samples were collected at the full flowering vegetation stage in 2018-2019. Phytochemical analysis was performed at the Faculty of Pharmacy at Lithuanian University of Health Science in 2019-2020.

\section{Meteorological factors}

Hydrometeorological data were used from the bulletins of the Lithuanian Hydrometeorological Service. Hydrothermal coefficient (HTC) was calculated according to the formula HTC $=\mathrm{H} / 0.1 \Sigma \mathrm{T}$, where $\mathrm{H}$ is the precipitation $\mathrm{mm}$ and $\Sigma \mathrm{T}$ is the sum of average active temperatures $t^{\circ} \mathrm{C}[3]$. The phenological observations were performed during the vegetation period twice a week.

\section{Extraction of essential oils}

The preparation of essential oils was done using a modified standard procedure according to the European Pharmacopoeia [22]. The raw material (leaves, stems, flowers) of A. pontica was dried at $25^{\circ} \mathrm{C}$ temperature in a ventilated lodge avoiding direct solar radiaton for 8 weeks. The dried material was stored in a dark room at ambient temperature and used for further analysis. The essential oils were obtained by hydrodistillation using a closed type Clevenger apparatus. In brief, $15 \mathrm{~g}$ of the dried material was mixed with $500 \mathrm{~mL}$ distilled water and submitted to extraction for $3 \mathrm{~h}$ until no more essential oils were obtained. The light blue coloured oil with a pleasant aroma was stored in a refrigerator at $+4^{\circ} \mathrm{C}$ until further use.

\section{Gas chromatography-mass spectrometry (GC- MS) analysis}

The analysis of essential oils was performed using gas chromatography with a mass spectrometer detector (GC-MS-QP2010, Shimadzu, Tokyo, Japan) equipped with a Shimadzu autoinjector AOC-5000 (Shimadzu, Tokyo, Japan). Separation of compounds was performed on a RXI-5MS column $(30 \mathrm{~m} \times 0.25 \mathrm{~mm}$ i.d. $\times 0.25 \mu \mathrm{m}$ film thickness $)$ (Restec, Bellefonte, USA). The operational conditions were as follows: temperature program from $50^{\circ} \mathrm{C}(5 \mathrm{~min})$ to $200^{\circ} \mathrm{C}$ at $2^{\circ} \mathrm{C} / \mathrm{min}$ and to $315^{\circ} \mathrm{C}$ $(15 \mathrm{~min})$ at $15^{\circ} \mathrm{C} / \mathrm{min}$. The GC-MS-QP2010 was equipped with a split/splitless injector $\left(260^{\circ} \mathrm{C}\right)$. Split ratio: 1:60. Inlet pressure: $70.2 \mathrm{kPa}$. Carrier gas: helium (purity $>99 \%$ ), delivered at constant linear velocity $40 \mathrm{~cm} / \mathrm{s}$. Interface temperature: $280^{\circ} \mathrm{C}$. MS ionization mode: electron ionization. Detector voltage: $0.99 \mathrm{kV}$. Acquisition mass range: 29-500 u. Scan speed: $2500 \mathrm{amu} / \mathrm{s}$. Acquisition mode: full scan, scan interval $0.20 \mathrm{~s}$.

\section{Identification and quantification of volatiles}

The percentage composition of essential oils was computed from GC peak areas without correction factors. Qualitative analysis was based on a comparison of retention times, indexes and mass spectra with the corresponding data in the literature [2] and NIST/FFSNC computer mass spectra libraries.

To verify the possible association between the compounds of essential oils selected along with meteorological factors (average of active temperature and precipitation) the Pearson's correlation 
analysis was used. A value of $p<0.05$ was taken as the level of significance [23].

\section{RESULTS AND DISCUSSION}

\section{The influence of meteorological factors for accumulated essential oils}

Different environmental conditions and meteorological factors during the plant vegetation period help them to survive and accumulate biologically active compounds [17]. The meteorological factors in the period of investigations are presented in the Figure.

The earliest beginning of vegetation and the optimal climatic conditions for Artemisia pontica L. growth were at the time when HTC was 1.321.35. The vegetation of this perennial plant starts at the earliest on the 97th-102th days of the year (April). The full flowering vegetation period starts on the 237th-25th days (August-September) of the year. The longest period (42 days) of full flowering was determined in 2019 when the sum of average active temperatures was $3375.9^{\circ} \mathrm{C}$. The earliest end of the vegetation period of $A$. pontica was at the time when HTC $=1.7$ (most humidity). Our phenological observations and dynamic of HTC confirms that Artemisia L. genus plants best tolerate dry air conditions [1, 5].

The obtained results showed that the statistically significant highest amount and diversity of compounds $(p<0.05)$ from Artemisiae pon- tici herba essential oils were investigated in 2018 when HTC $=1.32$. Through the Pearson's linear correlation analysis it was determined that the average of active temperatures was strongly correlated ( $r=0.740)$ with the amount of precipitation. The content of compounds in 2019 was by $33.3 \%$ lower when HTC $=0.91$ (mild drought $)(p<0.05)$.

In the previous study in Lithuania, the results showed that meteorological factors differently influenced the accumulation of compounds in Thymus sp. [18]. The differences found between our results and those of other authors can be attributed to the fact that essential oils are a heterogeneous group of mixtures that are affected by meteorological factors.

Our analyses showed that the oils isolated from different years differed in composition. The essential oil yields (v/w, on dried mass basis) of Artemisiae pontici herba ranged from 0.3 to $0.8 \%$ in 2018-2019. The results of the analysis of essential oils are presented in the Table and expressed in arbitrary units of the peak area in a GC/MS chromatogram. The GC/MS peak area was selected for quantitative purposes because the interpretation by using a percentage composition would not be suitable due to a different number of compounds; anyway, the range of the percentage composition of all compounds at different vegetation periods is given.

The highest content and diversity of compounds have been obtained from Artemisiae pontici herba essential oils during the 2018 vegetation period. In

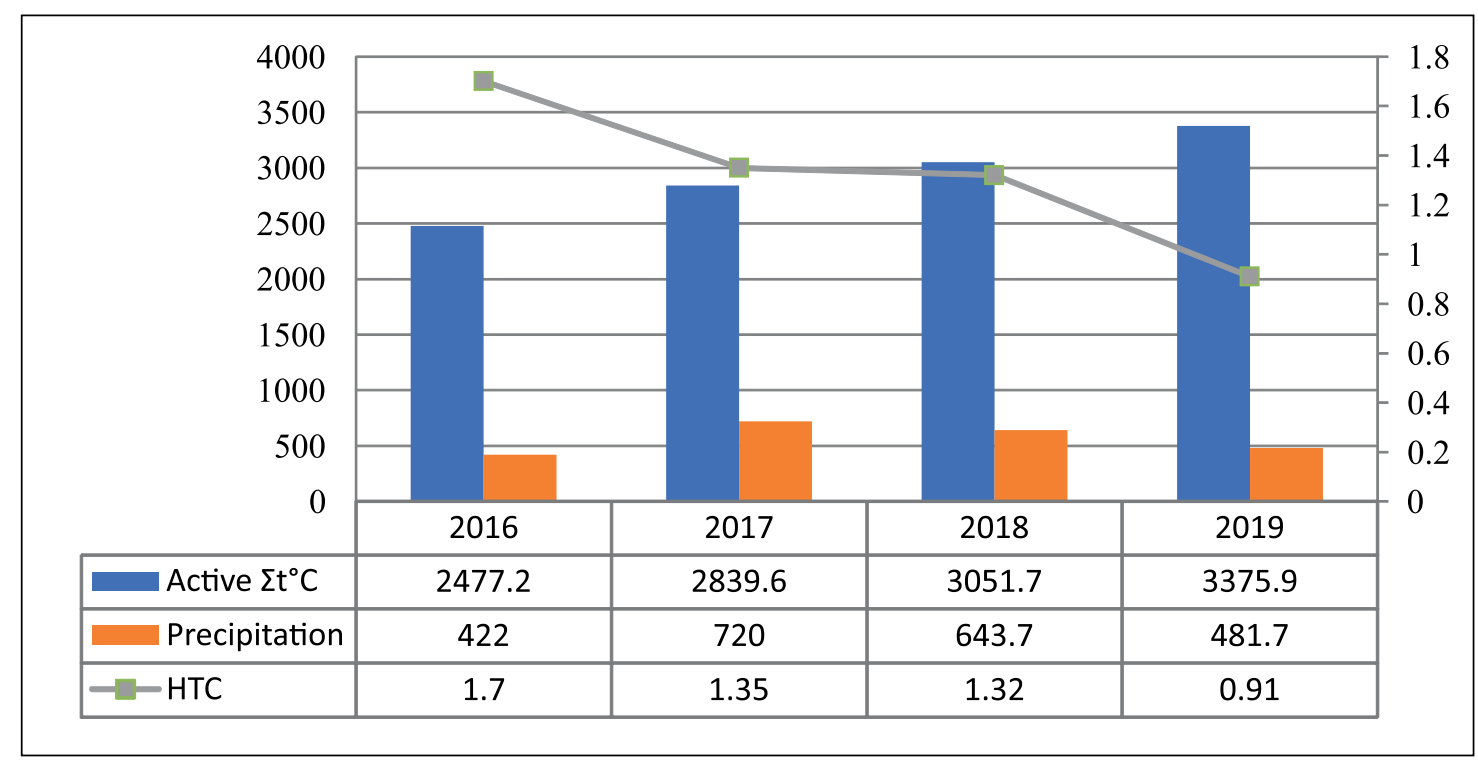

Figure. Dynamics of meteorological factors (sum average active temperatures $\Sigma \mathrm{t}^{\circ} \mathrm{C}$, amount of precipitation mm and hydrothermal coefficient HTC) during the vegetation period (May-0ctober, 2016-2019) (coloured online) 
Table. Variation of the essential oil composition of Artemisiae pontici herba collected during the vegetation period in the Botanical Garden at Vytautas Magnus University, 2018-2019

\begin{tabular}{|c|c|c|c|}
\hline Compounds & $\mathbf{R} \mathbf{I}$ & Amount (\%) GC/MS2018 year & Amount (\%) GC/MS2019 year \\
\hline 2-Pinene & 910 & - & 0.07 \\
\hline (+)-Camphene & 928 & - & 1.73 \\
\hline 4(10)-Thujene & 948 & 0.06 & 0.59 \\
\hline a-Pinene & 954 & 0.41 & - \\
\hline$\beta$-Myrcene & 956 & 0.06 & - \\
\hline a-Terpinene & 1000 & 1.25 & 0.52 \\
\hline a-Phellandrene & 1011 & - & 0.05 \\
\hline 1,4-Cineole & 1013 & 37.92 & - \\
\hline 1,8-Cineole & 1015 & - & 46.86 \\
\hline $\mathrm{Y}$-Terpinene & 1063 & 1.25 & 1.34 \\
\hline$\beta$-Phellandrene & 1041 & 2.14 & - \\
\hline cis-Sabinene hydrate & 1049 & 0.19 & - \\
\hline Isoneral & 1063 & 0.03 & - \\
\hline a-Terpinolene & 1069 & 0.08 & 0.19 \\
\hline a-Thujone & 1097 & 0.12 & - \\
\hline Camphor & 1122 & 29.41 & 33.02 \\
\hline endo-Borneol & 1127 & 8.21 & - \\
\hline 2-Methyl-4,5-nonadiene & 1132 & 0.05 & 0.30 \\
\hline Isogeraniol & 1144 & 0.23 & - \\
\hline 2-Bornanol & 1146 & - & 5.56 \\
\hline Terpinen-4-ol & 1151 & 0.19 & 3.46 \\
\hline 4-Thujanol & 1157 & 5.24 & 0.22 \\
\hline Terpineol & 1159 & 0.24 & 0.33 \\
\hline 2-Pinen-10-ol & 1172 & - & 0.21 \\
\hline 2-Methyl-3-phenylpropanal & 1218 & 0.61 & - \\
\hline cis-Piperitol & 1189 & 0.20 & - \\
\hline Isobornyl formate & 1256 & 0.14 & - \\
\hline Sabinol & 1267 & - & 0.10 \\
\hline trans-Sabinyl acetate & 1275 & 0.11 & - \\
\hline a-Cubebene & 1352 & 0.07 & - \\
\hline (-)-.ß.-Caryophyllene & 1387 & 0.45 & 0.79 \\
\hline Aromandendrene & 1394 & 0.91 & - \\
\hline a-Humulene & 1426 & 0.34 & 0.08 \\
\hline trans-a-Bergamotene & 1428 & 0.10 & - \\
\hline (E)- $\beta$-Famesene & 1439 & 0.48 & - \\
\hline cis-. $\beta$.-Farnesene & 1446 & - & 0.27 \\
\hline (-)- Germacrene D & 1453 & - & 3.24 \\
\hline Isogermacrene D & 1454 & 2.71 & - \\
\hline Y-Amorphene & 1458 & 0.03 & - \\
\hline (.+-.)-Lepidozene & 1460 & - & 0.12 \\
\hline Bicyclogermacrene & 1470 & 0.15 & - \\
\hline Sabinol isovalerate & 1493 & 0.08 & - \\
\hline Valeric acid & 1537 & 0.10 & - \\
\hline
\end{tabular}


Table. (Continued)

\begin{tabular}{c|cccc}
\hline Compounds & RI & Amount (\%) GC/MS2018 year & Amount (\%) GC/MS2019 year \\
\hline Caryophyllene oxide & 1554 & - & 0.35 \\
\hline Total & & $\mathbf{8 1 . 4 1 - 9 2 . 8 6}$ & $\mathbf{8 4 . 6 7 - 9 9 . 3 7}$ \\
\hline Monoterpene hydrocarbons & $6.61-7.80$ & $4.02-4.14$ \\
\hline Oxygenated monoterpenes & $74.19-75.73$ & $78.21-81.04$ \\
\hline Sesquiterpene hydrocarbons & $4.24-5.35$ & $5.45-6.70$ \\
\hline Oxygenated sesquiterpenes & $5.86-6.02$ & $7.80-9.90$ \\
\hline
\end{tabular}

the case study of $A$. pontica, 33 compounds were identified representing $64.7 \%$ of the oil. 1,4-cineole (37.92\%) present at a high percentage, camphor (29.41\%), endo-borneol (8.21\%) and 4-thujanol (5.24\%) made up $80.78 \%$ of the oil. In 2018 , all identified compounds made up $81.41-92.86 \%$ and in 2019 they made up $84.67-99.37 \%$ of the total content.

During the 2019 vegetation period, 22 compounds were identified representing $81.4 \%$ of the oil. 1,8-cineole (46.86\%) present at a high percentage, camphor (33.02\%) and 2-bornanol (5.56\%) made up $85.44 \%$ of the oil.

The main compounds found in the Artemisiae pontici herba essential oils were 1,8-cineole (46.86\%), 1,4-cineole (37.92\%), camphor (29.41$33.02 \%)$, endo-borneol (8.21\%) and 2-bornanol (5.56\%). As results show, camphor has been found as one of the first principal compounds in the 20182019 vegetation period of $A$. pontica (29.41$33.02 \%)$ in Lithuania. Monoterpenoids comprised a large part of $A$. pontica oils in the study. Oxygenated monoterpenes (74.19-81.04\%) formed more than half of oil content.

According to the published data, high levels of 1,8-cineole (25.2\%), a-thujone (23.2\%) and camphor $(16.0 \%)$ were also determined in the essential oils from A. pontica growing in Kazakhstan [10]. Some of our identified compounds in A. pontica samples were also found by Derwick et al.; however, the quantitative distribution of the compounds was a bit different. In the study of Derwick et al., the main compounds found in dried leaves were $\alpha$-thujone $(22.13 \%)$, sabinyl acetate $(3.89 \%)$ and $\beta$-thujone (2.56\%) [15]. The above-mentioned studies display different oil chemotypes, which correlate with different geographical locations, the plant material and method used for isolating the essential oils.
Our oils presented a similar chemical profile with several plants from the Artemisia L. genus, those obtained from populations growing in different locations from Lithuania. However, if we compare our results with those obtained studying other natural populations, we may notice both qualitative and quantitative differences [20, 21]. These differences consist in a lower amount of 1,8-cineole and camphor in the published data and in the absence of 1,4-cineole; they may be related to different geographical origins of the samples.

\section{CONCLUSIONS}

The chemical composition of essential oils of $A r$ temisia pontica L., introduced in the Collection of Medicinal Plants of the Scientific Sector of Medicinal and Aromatic Plants, Scientific Department of Botanical Garden at Vytautas Magnus University, was investigated in 2018-2020. The statistically significant maximum of content and diversity of compounds were determined when $\mathrm{HTC}=1.32$ (optimal climatic conditions). A strong correlation $(r=0.740)$ was assessed between the average of active temperatures and precipitation in 2019. The content of compounds was by $33.3 \%$ lower when HTC $=0.91$ (mild drought). The data obtained in this study showed that the essential oils composition of Artemisiae pontici herba was characterized by a high percentage of 1,8-cineole $(46,86 \%), 1,4$-cineole $(37.92 \%)$ and camphor (29.41-33.02\%).

Received 2 September 2020 Accepted 24 september 2020

\section{References}

1. M. J. Abad, L. M. Bedoya, L. Apaza, P. Bermejo, Molecules, 17, 2542 (2012). 
2. R. P. Adams, Identification of Essential Oil Components by GC/MS, Allured Publishing Corp., Carol Stream, IL (1995).

3. A. Dirsè, Žemès ūkio mokslai, 3, 51 (2001).

4. T. Efferth, Curr. Drug Targets, 7, 407 (2006).

5. V. Galinis, M. Natkevičaitè-Ivanauskienè, R. Jankevičienè, A. Lekavičius (ed.), Lietuvos TSR Flora, 6, 120 (1980).

6. M. Hurabielle, F. Tillequin, M. Paris, Planta Med., 31, 102 (1977).

7. F. Juteau, V. Masotti, J. M. Bessière, M. Dherbomez, J. Viano, Fitoterapia, 73, 53 (2002).

8. D. W. Lachenmeier, J. Ethnopharmacol., 131, 224 (2010).

9. X. Z. Su, L. H. Miller, Sci. China Life Sci., 58, 1175 (2015).

10. N. A. Talzhanov, D. T. Sadyrbekov, F. M. Smagulova, et al., Chem. Nat. Comp., 41(2), 178 (2005).

11. A. B. Trendafilova, Phytochemistry, 42(2), 471 (1996).

12. J. Vallès, S. Garcia, O. Hidalgo, et al., Adv. Bot. Res., 60, 349 (2011).

13. A. Viljoen, S. Van Vuuren, E. Ernst, et al., J. Ethnopharmacol., 88, 137 (2003).

14. Y. Waseem, C. A. Hasan, F. Ahmed, Cureus, 10, 1 (2018).

15. E. Derwich, Z. Benziane, A. Boukir, Elec. J. Envir. Agric. Food Chem., 8, 1202 (2009).

16. A. K. Pandey, P. Singh, Medicines, 4, 1 (2017).

17. A. Ebrahimi, P. Moaveni, A. T. Dashtbozorg, H. A. Farahani, J. Agric. Ext. Rural Dev., 3, 19 (2011).

18. V. Vaičiulytė, K. Ložienè, Ind. Crops Prod., 77, 491 (2015).

19. M. De Vincenzi, M. Silano, A. De Vincenzi, F. Maialetti, B. Scazzocchio, Fitoterapia, 73(3), 269 (2002).

20. A. Judžentiené, J. Buzelyte, Chemija, 17, 12 (2006).

21. A. Judžentienè, D. Mockutè, Chemija, 15, 64 (2004).

22. European Pharmacopoeia, 9th edn., 1563 (2017).
23. V. Čekanavičius, G. Murauskas, Statistika ir jos taikymai I, 145, Vilnius (2001).

24. World Health Organization (WHO), Global Technical Strategy for Malaria, 2016-2030, 11 (2015).

Sandra Saunoriūtè, Ona Ragažinskienè,

Liudas Ivanauskas, Mindaugas Marksa,

Erika Šeinauskienė

\section{METEOROLOGINIŲ VEIKSNIŲ ITAKA PONTINIO KIEČIO (ARTEMISIA PONTICA L.) FITOCHEMINEI SUDE்ČIAI}

Santrauka

Plečiant vaistinių augalų ir juose susikaupusių biologiškai veikliujų junginių ịvairovę, dèmesys atkreiptas ỉ kiečio (Artemisia L.) genties augalų introdukciją Lietuvoje. Tyrimo tikslas - nustatyti introdukuoto ir Lietuvos klimato sąlygomis auginamo pontinio kiečio (Artemisia pontica L.) eterinių aliejų kiekybę ir kokybę. Tyrimo objektas - vaistinè augalinè žaliava Artemisiae pontici herba, 2018-2019 m. tyrimams paruošta Vytauto Didžiojo universiteto Botanikos sodo Mokslo skyriuje, Vaistinių ir prieskoninių augalų mokslo sektoriuje. Eteriniai aliejai išskirti hidrodistiliacijos metodu, ju sudètis išanalizuota dujų chromatografijos / masių spektrometrijos metodais 2018-2020 m. Lietuvos sveikatos mokslų universiteto Farmacijos fakultete. Atlikus tyrimus identikuotu junginių skaičius statistiškai reikšmingai skyrèsi, priklausomai nuo meteorologinių sąlygų $(p<0,05)$. Maksimalus junginių kiekis nustatytas 2018 m., kai HTK = 1,32 (optimalios drégnumo sąlygos). Nustatyta stipri koreliacija $(r=0,740)$ tarp vidutinès aktyvios oro temperatūros ir kritulių kiekio. 2019 m. nustatytas junginių skaičius $33 \%$ mažesnis, kai HTK = 0,91 (silpna sausra). Vyraujantys lakieji junginiai: 1,8-cineolis $(46,86 \%), 1,4$-cineolis (37,92 \%) ir kamparas (29,41-33,02\%). 